\title{
PENANGGULANGAN PENYAKIT MAS (MOTILE AEROMONAS SEPTICEMIA) PADA IKAN NILA MENGGUNAKAN EKSTRAK TEMULAWAK (CURCUMA XANTHORRIZA ROXB)
}

\section{Prevention of MAS (Motile Aeromonas Septicemia) in Tilapia Using Temulawak Extract (Curcuma xanthorriza Roxb)}

\author{
Fariq Azhar*), Muhammad Junaidi, Alis Muklis, Andre Rachmat Scabra \\ Program Studi Budidaya Perairan, Universitas Mataram. \\ JI. Pendidikan No. 37 Kota Mataram, Provinsi NTB \\ *Alamat korespondensi : fariqazhar@unram.ac.id
}

(Tanggal Submission: 29 November 2019, Tanggal Accepted: 28 Desember 2020)

\begin{abstract}
ABSTRAK
Masalah penyakit pada ikan merupakan salah satu kendala utama yang dihadapi oleh para pembudidaya karena berpotensi menimbulkan kerugian yang sangat besar seperti penurunan hasil produksi, dan kematian massal pada ikan. Aeromonas hydrophila merupakan salah satu jenis bakteri pathogen yang dapat menimbulkan penyakit Motile Aeromonas Septicemia atau lebih dikenal dengan penyakit MAS pada ikan nila (Oreochromis niloticus). Aeromonas hydrophila dapat menyebabkan bercak merah pada ikan nila dan berakibat pada kematian ikan. Pemberian antibiotik yang bersifat kimia secara terus menerus dapat mengakibatkan terjadinya resistensi bakteri terhadap jenis antibiotik tersebut. Selain itu, efek samping pemberian antibiotik dapat meninggalkan residu yang nantinya akan membahayakan manusia dan lingkungan. Penggunaan bahan alami yang mempunyai senyawa antimikrobia seperti temulawak (Curcuma xanthorriza Roxb) diharapkan mampu sebagai pengganti bahan kimia antibiotik dan membantu meningkatkan sistem imun dari ikan tersebut. Penggunaan bahan alami jauh lebih ramah lingkungan, murah, dan tidak bersifat karsinogen. Penyuluhan dilakukan dengan metode Focus Group Discussion (FGD) di desa Gontoran Kecamatan Lingsar Kabupaten Lombok Barat. Hasil kegiatan ini cukup baik, yakni mampu mendorong masyarakat untuk dapat menangani dan mencegah penyebaran penyakit bakterial khususnya penyakit MAS pada ikan nila dengan penggunaan bahan alami, sehingga penggunaan antibiotic sintesis dapat diminimalisir dan mengurangi biaya produksi pada proses pemeliharaan.
\end{abstract}

Keyword: ikan nila, Aeromonas hydrophila, Curcuma xanthorriza Roxb. 


\section{PENDAHULUAN}

Masalah penyakit pada ikan merupakan salah satu kendala utama yang dihadapi oleh para pembudidaya karena berpotensi menimbulkan kerugian yang sangat besar seperti penurunan hasil produksi, dan bahkan kematian masal pada ikan. Menurut Ashari et al. (2014), munculnya penyakit pada ikan merupakan akibat dari faktor inang (ikan) yang lemah, adanya mikrorganisme pathogen dan kualitas lingkungan yang buruk. Penyakit pada ikan dapat disebabkan oleh beberapa jenis pathogen, seperti virus, parasit, jamur, dan bakteri. Gejala yang ditunjkkan oleh ikan yang terkena penyakit akibat bakteri biasanya seperti kehilangan nafsu makan, luka-luka pada permukaan tubuh, pendarahan pada insang, perut membesar berisi cairan, sisik dan sirip ekor lepas, dan jika dilakukan pembedahan akan terlihat pembekakan serta kerusakan pada hati, ginjal dan limpa ikan (Lubis, 2014).

Aeromonas hydrophila merupakan salah satu jenis bakteri pathogen yang dapat menimbulkan penyakit pada ikan. Menurut Lukistiyowati et al. (2012), Aeromonas hydrophila termasuk bakteri gram negatif, berbatang pendek bersifat aerob dan fakultatuf anaerob, tidak berspora, motil, mempunyai satu flagel, dan hidup pada kisaran suhu $25-30^{\circ} \mathrm{C}$. Bakteri ini dapat menimbulkan penyakit Motile Aeromonas Septicema atau lebih dikenal dengan penyakit MAS pada ikan nila (Oreochromis niloticus). Aeromonas hydrophila dapat menyebabkan bercak merah pada ikan nila (Firnanda, 2013). Menurut Sari et al. (2013), bakteri Aeromonas hydrophila menggunakan sistem quorum sensing sebagai pengontrol virulensinya terhadap organisme lain, sehingga sistem quorum sensing dapat dijadikan sebagai target untuk agen pada bakteri. Pengunaan bahan alami dapat dilakukan untuk menghambat sistem quorum sensing bakteri sebagai alternatif untuk mengatasi infeksi tanpa menggunakan agen yang dapat menyebakan resistensi bakteri. Menurut Samsundari et al, (2006), Penggunaan antibiotik berupa bahan kimia sebagai pengobatan untuk ikan yang sakit ternyata memberikan efek yang kurang baik bagi lingkungan dan ikan itu sendiri. Semakin lama terpapar antibiotik akan menyebabkan bakteri tersebut resisten terhadap antibiotik yang diberikan. Selain itu, lingkungan disekitar tempat budidaya tersebut akan berpeluang untuk terjadinya mutasi. Oleh sebab itu, penggunaan antibiotik tertentu sudah dilarang oleh pemerintah dan lebih dianjurkan untuk mengunakan bahan alami yang bersifat herbal (fitofarmaka).

Bahan-bahan alami dipilih karena lebih ramah lingkungan, dan tidak bersifat karsinogen. Salah satu fitofarmaka yang mempunyai efek sebagai anitimikrobial adalah temulawak (Curcuma xanthorrhiza Roxb). Menurut Sari et al. (2012), rimpang temulawak mengandung kurkumin, serat, pati, kalium oksalat, flavonoid, dan minyak atsiri yang berfungsi sebagai antimikroba.

\section{METODE KEGIATAN}

Metode yang digunakan dalam penyuluhan ini adalah Focus Group Discusion (FGD) dengan memberikan informasi atau wawasan kepada pembudidaya terkait penyakit yang disebabkan oleh bakteri Aeromonas hydrophila sehingga dapat memberikan solusi tentang cara penanggulangan penyakit Motile Aeromonas Septicema atau lebih dikenal dengan penyakit MAS pada ikan nila kepada pembudidaya. Mulai dari menyampaikan informasi tentang 
cara pemilihan bibit ikan nila, petunjuk pengelolaan budidaya ikan nila, Petunjuk penanganan ikan yang terserang penyakit Aeromonas hydriphila dan pemanfaatan bahan alami sebagai pengganti antibiotik.

Kegiatan penyuluhan ini dilaksanakan di desa Gontoran, Kecamatan Lingsar, Kabupaten Lombok Barat, Nusa Tenggara Barat. Sasaran kegiatan penyuluhan ini adalah para pembudidaya ikan nila yang sudah lama menekuni usaha tersebut.

\section{HASIL DAN PEMBAHASAN}

Kegiatan pengabdian berjalan lancar dan cukup baik, hal ini ditandai dengan antusiasme masyarakat khususnya para pembudidaya untuk menghadiri kegiatan penyuluhan, dan pada saat proses diskusi berlangsung para pembudidaya cukup aktif mengungkapkan pendapat serta bertanya terkait materi diskusi yang dibahas. Kegiatan penyuluhan ini dilaksanakan di desa Gontoran, Kecamatan Lingsar, Kabupaten Lombok Barat, Nusa Tenggara Barat dengan menyampaikan informasi kepada masyarakat tentang cara pemilihan bibit ikan nila, petunjuk pengelolaan budidaya ikan nila, petunjuk penanganan ikan yang terserang penyakit Aeromonas hydriphila dan pemanfaatan bahan alami sebagai pengganti antibiotik. Metode yang digunakan dalam penyuluhan ini adalah Focus Group Discusion (FGD) (gambar 1.) dengan memberikan informasi atau wawasan kepada pembudidaya terkait penyakit yang disebabkan oleh bakteri Aeromonas hydrophila sehingga dapat memberikan solusi tentang cara penanggulangan penyakit Motile Aeromonas Septicema atau lebih dikenal dengan penyakit MAS pada ikan nila kepada pembudidaya.

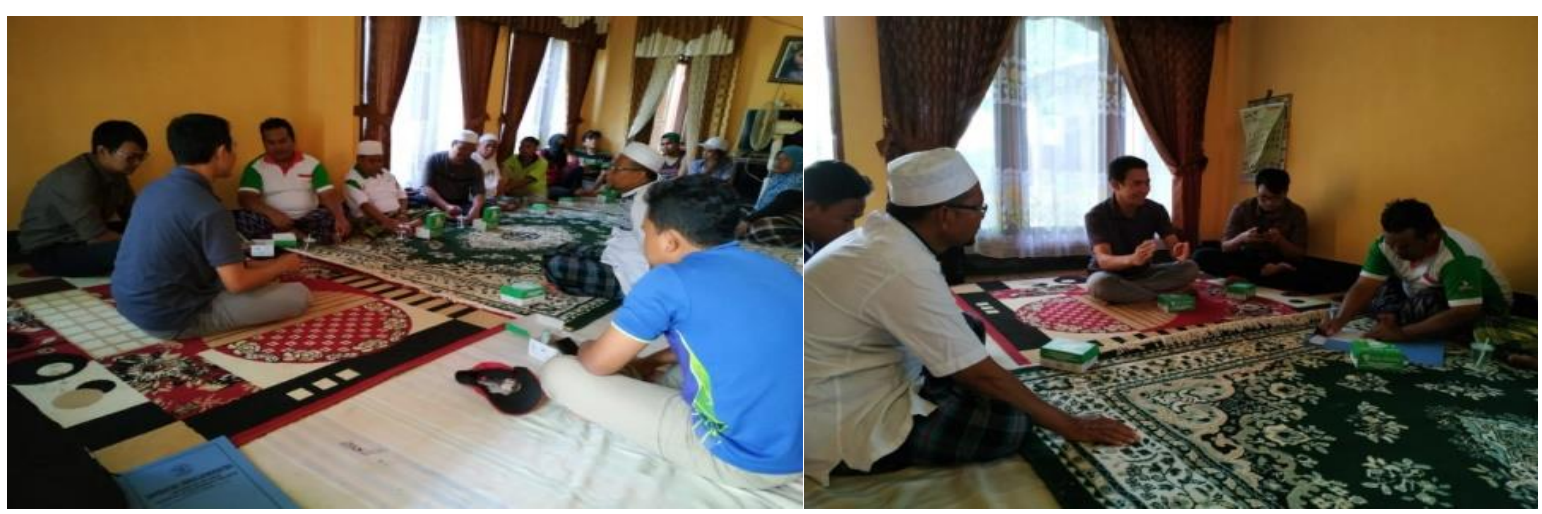

Gambar 1. Kegiatan Penyuluhan (dokumen pribadi).

Penyakit Aeromonas hydrophila yang merupakan salah satu jenis bakteri pathogen dapat menimbulkan penyakit Motile Aeromonas Septicemia atau lebih dikenal dengan penyakit MAS pada ikan nila (Oreochromis niloticus). Penyakit ini dapat menyebabkan bercak merah pada ikan nila, hilangnya nafsu makan ikan, dan gejala klinis lainnya yang dapat berakibat pada kematian ikan dan kerugian bagi para pembudidaya.
Penanggulangan penyakit pada ikan biasanya dilakukan dengan pemberian antibiotik namun pemberian antibiotik sintesis dapat menyebabkan pencemaran lingkungan dan residu bagi biota budidaya sehingga lebih disarankan menggunakan bahan alami yang bersifat herbal.

Penyuluhan mengenai penggunaan bahan alami untuk penanggulangan penyakit ikan diberikan kepada para pembudidaya ikan 
nila agar dapat meningkatkan produksi dan dapat mengurangi kematian yang diakibatkan oleh bakteri ataupun lingkungan yang buruk. Pemberian bahan alami berupa temulawak (Curcuma xanthorrhiza Roxb) dengan kandungan senyawa aktif berupa minyak atsiri dan flavonoid diharapkan mampu membantu meningkatkan kualitas sistem imun ikan, sehingga dapat tahan terhadap infeksi bakteri yang dapat mengakibatkan penyakit Motile Aeromonas Septicemia atau lebih dikenal dengan penyakit MAS pada ikan nila. Peningkatkan kualiatas sistem imun akan berbanding lurus dengan kelangsungan hidup ikan nila selama masa pemeliharaan. Dengan sistem imun yang baik maka tingkat kelangsungan hidup ikan juga akan meningkat. Sistem imun yang meningkat tersebut diharapkan dapat menjadi pertahanan yang ampuh dalam menghalau penyakit.

Pemilihan temulawak (Curcuma xanthorrhiza Roxb) sebagai bahan alami untuk menanggulangi penyakit bakteri pada ikan nila dikarenakan temulawak (Curcuma xanthorrhiza Roxb) memiliki kandungan senyawa aktif berupa minyak atsiri dan flavonoid yang dapat digunakan sebagai antibiotik alami. Minyak atsiri berfungsi sebagai antibakteri dan antiseptik. Mekanisme kerja senyawa fenol yang terkandung dalam minyak atsiri dapat mematikan atau membunuh bakteri dengan cara menghancurkan dinding sel dan protein bakteri sehingga senyawa ini efektif digunakan sebagai antibakteri. Menurut Zalinar (2003), pada fraksi minyak atsiri terdapat kandungan xanthorrizol sekitar $11,6 \%$ yang kemampuannya dapat merusak ikatan peptidoglikan sehingga minyak atsiri mampu menembus dinding sel bakteri dan melumpuhkannya. Senyawa aktif lainnya yang terkandung dalam temulawak adalah flavonoid yang dapat berfungsi sebagai zat antiradang, yang dapat memperkuat dinding kapiler sel-sel darah. Menurut Santoso (2016), flavonoid merupakan salah satu zat yang tergolong senyawa fenol. Zat tersebut mudah larut dalam air dan dapat bersifat lipofilik yang memiliki kemampuan untuk merusak dinding sel mikroba sehingga dapat bersifat sebagai bakterisidal, meningkatkan mekanisme phagositik sel-sel darah putih dan meningkatkan kinerja organ limpoid dalam menghasilkan sel-sel leukosit yang dapat bermanfaat sebagai pemakan atau penghancur sel- sel bakteri yang masuk ke dalam tubuh biota. Sifat senyawa ini yang mudah larut dalam air secara tidak langsung dapat mengurangi limbah budidaya dan pencemaran lingkungan.

Dengan memanfaatkan bahan alami dari ekstrak herbal diharapkan mampu membantu penanggulanagan penyakit yang diakibatkan oleh serangan bakteri, sehingga dapat membantu mengurangi penggunaan antibiotic sintesis yang dapat menyebabkan pencemaran lingkungan dan mampu membantu meningkatkan sistem imun pada ikan, sehingga ikan nila yang dibudidayakan mampu melawan serangan pathogen. Dengan sistem imun atau sistem kekebalan tubuh yang baik terhadap pathogen maka pertumbuhan ikan juga akan cepat dan kendala dalam proses budidaya dapat dikurangi.

\section{KESIMPULAN DAN SARAN}

Kesimpulan

Penyuluhan tentang pemberian bahan alami yang bersifat herbal berupa temulawak (Curcuma xanthorrhiza Roxb) dengan kandungan senyawa aktif berupa minyak atsiri dan flavonoid yang memiliki khasiat sebagai antibakteri dan antiradang diharapkan mampu menjadi solusi untuk menangani masalah penyakit Motile Aeromonas Septicemia (MAS) 
yang menyerang ikan nila (Oreochromis niloticus) di Desa Gontoran Kecamatan Lingsar Kabupaten Lombok Barat, sehingga dapat menghindari adanya resistensi bakteri, residu pada biota budidaya dan pencemaran lingkungan perairan serta dapat meningkatkan hasil produksi para pembudidaya.

Saran

Bahan alami yang bersifat antibakterial sangat banyak ditemukan di alam, diharapkan penanggulangan penyakit pada ikan dapat menggunakan bahan alami lainnya yang ada di alam.

\section{DAFTAR PUSTAKA}

Ashari, C., Tumbol, R A., Kolopita, M. E. 2014. Diagnosa Penyakit Bakterial pada Ikan Nila (Oreochromis niloticus) yang Dibudidaya pada Jaring Tancap di Danau Tandono. Budidaya Perairan. 2 (3).2430.

Firnanda, R., Sugito., Fakhrurrozi., Ambarwati, Defi. 2013. Isolasi Aeromonas hydrophila pada Sisik Ikan Nila (Oreochromis niloticus) yang Diberi Tepung Daun Jaloh (Salix tetrasperma Roxb). 7 (1). 22-24.

Lubis Y. P. P., Yunasfi. 2014. Jenis Jenis Bakteri pada Luka Ikan Patin. Journal Aquacostamarine. 2 (1). 66-71.

Lukistiyowati, I., Kurniasih. 2012. Pelacakan Gen Aerolysin dari Aeromonas hydrophila pada Ikan Mas yang Diberi Pakan Ekstrak Bawang Putih. Jurnal Veteriner. 13 (1). 43-50.

Samsundari, Sri. 2006. Pengujian Ekstrak Temulawak dan Kunyit Terhadap Resistensi Bakteri Aeromonas hydrophilla yang Menyerang Ikan Mas (Cyprinus carpio). Gamma. 11 (1). 71-83. Santoso, B., Rifqi, S. U., Muhammad , D. W. 34 Agustus 2016. Analisis Hubungan Senyawa Golongan Flavonoid Dari 24 Famili Tanaman Terhadap Aktivitas Penangkap Radikalnya. Prosiding Seminar Nasional Kimia UNJANI-HKI. Bandung.

Sari, D. S., Pangastuti, A., Herawati, E. 2013. Pencegahan Infeksi akteri Aeromonas hydrophila pada Ikan Nila (Oreochromis niloticus) dengan Pemberian Ekstrak Etil Asetat Rimpang Temu Ireng (Curcuma aeruginosa). 11 (2). 31-35.

Sari, N. Winda., Lukistyowati, I., Aryani, N. 2012. Pengaruh Pemberia Temulawak (Curcuma xanthorriza Roxb) terhadap Kelulushidupan Ikan Mas (Cyprinus carpio L) setelah Diinfeksi Aeromonas hydrophila. 17 (2). 43-59.

Zalinar, udin. 2003. Sitoksisitas xanthorrizol dari Minyak Atsiri Rimbang Curcuma xanthorrizol Roxb. Terhadap Sel Kanker Payudara YBM 1 Indonesia. Journal of Applied Chemistry. 3(1): 1-12. 